Na pracę, która omówi wzrost znaczenia tego urzędnika po 1646 (tj. od mianowania na te stanowisko M. Potockiego), będziemy musieli jeszcze trochę poczekać, co wydaje się interesującym postulatem badawczym.

Mikołaj Tomaszewski (Toruń)

\title{
Henryk Litwin, Równi do równych: kijowska reprezentacja sej- mowa 1569-1648, Warszawa 2009, Wydawnictwo DiG, ss. 193
}

$\mathrm{T}$

ematyka parlamentaryzmu w Rzeczypospolitej szlacheckiej cieszy się niemalejącym zainteresowaniem historyków. Jednakże mimo obszernej literatury przedmiotu, wiele zagadnień obejmujących tę problematykę nie zostało dotąd opracowanych. Przede wszystkim brakuje prac, które w sposób kompleksowy opisywałyby reprezentację sejmową kresów południowo-wschodnich. Luka ta została przynajmniej częściowo załatana przez pracę pióra Henryka Litwina pt. Równi Do Równych: Kijowska reprezentacja sejmowa 1569-1648. Praca ta została opublikowana w 2009 r. przez wydawnictwo DiG.

Omawiana książka składa się ze wstępu, trzech rozdziałów, zakończenia, wybranej bibliografii oraz indeksu osobowego. Niewątpliwie zamysłem autora nie było tylko napisanie pracy, która miałaby przedstawiać sylwetki wybieranych posłów, ale również celem było ukazanie wszelkiego rodzaju danych statystycznych związanych z kadrą poselską województwa kijowskiego. Pewnym mankamentem pracy jest brak zamieszczenia w niej indeksu geograficznego. Byłby on wskazany ze względu na rozległość terytorialną województwa kijowskiego, które było najrozleglejsze na obszarze całej Rzeczypospolitej. Autor stawia sobie wiele pytań, ale nie zawsze w pełni na nie odpowiada, a powodem są braki źródłowe.

Monografia została oparta na niezbyt szerokiej bazie archiwalnej. Henryk Litwin przeprowadził kwerendę tylko w pięciu zagranicznych instytucjach, które grupują materiały niezbędne do badania tej problematyki. Autor oparł swoją pracę m.in. na materiałach przechowywanych w Nacional'na Biblioteka Ukrajiny im. H. Vernads'koho czy w Centralnyj Derzavnyj Istorycnyj Archiv Ukrajiny u misti Kyjevi. Warto zaznaczyć, że autor niniejszej monografii odnalazł interesujące materiały w Archivum Secreteum Vaticanum. Oprócz wymienionych wyżej archiwów

\section{3}


autor poszukiwał niezbędnych źródeł m.in. w Archiwum Głównym Akt Dawnych w Warszawie, w Archiwum Państwowym: w Krakowie i Lublinie, w Archiwum Romanum Societatis Iesu, w Bibliotece Narodowej w Warszawie, czy też w Bibliotece Jagiellońskiej w Krakowie.

O wiele lepiej przedstawia się baza źródeł wydanych drukiem oraz literatura przedmiotu. Kluczowe znaczenie dla pracy mają oczywiście akta sejmikowe i diariusze, które mogą dostarczyć nam szereg interesujących informacji na badany temat.

We wstępie autor uzasadnił wybór tematu, przedstawił swoje cele badawcze, zakres chronologiczny i geograficzny pracy. Został zreferowany również dotychczasowy stan badań nad opracowywanym zagadnieniem oraz pobieżnie została potraktowana baza źródłowa, z jakiej autor korzystał, pisząc monografię.

Rozdział pierwszy rozpoczyna się podstawowymi informacjami na temat zasięgu, siedzib i liczebności kijowskiej reprezentacji sejmowej. Następnie Henryk Litwin przedstawił analizę całej tej zbiorowości. Wszystkie ustalenia zostały przedstawione w tabelach, które mogą nam dostarczyć wszelkiego rodzaju informacji dotyczących udziału w sejmach i wyznania danego przedstawiciela województwa kijowskiego. Jak można się domyślać, wyznanie prawosławne wiodło prym pod względem liczby wyznawców w kadrze poselskiej województwa kijowskiego w latach 1569-1648. Na dalszych miejscach znaleźli się wyznawcy katolicyzmu, arianizmu, kalwinizmu, a grupę tę zamykają Bracia Czescy.

Ciekawym rozwiązaniem przedstawionym przez autora w rozdziale pierwszym jest podzielenie kadry poselskiej na klasy majątkowe lat 1569-1648. Cała ta struktura składa się z kilku warstw: kniaziów, panów, ziemian i szlachtę napływową. W swoich rozważaniach autor oczywiście podał dane statystyczne dotyczące liczby posłowań. Autor słusznie zauważa, że przedstawiciele magnackiej i kniaziowskiej warstwy rzadziej pojawiali się w kijowskiej reprezentacji sejmowej. O wiele silniejszą pozycję mieli przedstawiciele rodów pańskich. Największym prestiżem wśród tych warstw majątkowych cieszyły się rodziny Aksaków, Butowiczów czy Hornostajów. Innym zestawieniem, na który warto zwrócić uwagę, jest przedstawienie rodów średniozamożnych (zaliczanych przez Henryka Litwina do IV grupy majątkowej). Wśród nich byli m.in. członkowie rodzin Sołtanów i Trypolskich.

System ustrojowy Rzeczypospolitej szlacheckiej był tak skonstruowany, że karierę poselską umożliwiał przede wszystkim pełniony urząd. Autor w swoich rozważaniach nie pominął tego zagadnienia, dzięki czemu mamy do czynienia z kolejnym zestawieniem, które przedstawia urzędników ziemskich i ich posłowania. Największy udział w posiedzeniach mieli podkomorzowie, a za nimi uplasowali się sędziowie, podsędkowie i pisarze. Ostatnim zestawieniem statystycznym, o jakim możemy w tym rozdziale mówić, jest tabela przedstawiająca rodzaj funkcji i funkcja potwierdzonych powołań na dany urząd. Autor uwzględnił tu: marszałów sejmi- 
ków, deputatów do trybunałów, sędziów kapturowych, rotmistrzów, poborców podatkowych, członków komisji powołanych na sejm do spraw lokalnych, członków komisji skarbowych oraz elektów na urząd sądowy.

Podsumowując, możemy powiedzieć, że w województwie kijowskim uznaniem cieszyły się bardziej zamożne rody. Potencjalni wyborcy bardziej przychylnym okiem patrzyli na kandydatów, którzy pełnili funkcje sądowe lub ziemskie. Jak sam autor słusznie zauważa, te rozważania przedstawione w pierwszym rozdziale wcale nie muszą wyczerpywać badanej tematyki.

Kolejny rozdział prezentowanej publikacji mówi o koneksjach i koligacjach poselstwa kijowskiego. Została tutaj podjęta próba scharakteryzowania powiązań, przede wszystkim politycznych, jakie łączyły środowiska szlachty kijowskiej ze sobą. Autor w tej części książki próbuje dokonać ustaleń dotyczących związków politycznych. Mówiąc o tym zagadnieniu, często w tym rozdziale jest poruszana tematyka klienteli. Nie zawsze jednak autorowi udaje się w pełni ustalić relacje polityczne wiążące szlachtę kijowską z magnaterią. Przykładem może być słabiej omówiona, a wręcz pominięta klientela Mikołaja Potockiego, który w owym czasie umacniał i to w dość dużym stopniu swoje wpływy na obszarze kijowszczyzny. Jednakże takich przykładów może być więcej. Słabo została również omówiona klientela innych rodów magnackich, jak np. Zbaraskich, Koniecpolskich czy Zasławskich.

Niniejszy rozdział składa się przede wszystkim ze skróconych biogramów wybieranych posłów na sejm w latach 1569-1648. Warto zauważyć, że w tym gronie również znalazł się Adam Kisiel, który posłował na sejm w latach 1628, 1633 i 1635. Autor w każdym z biogramów poświęca dość dużo miejsca koligacjom rodzinnym, które ułatwiały w pewien sposób karierę polityczną. Biogramy umieszczone w tej części książki ukazują zaplecze polityczne posłów wybranych na sejm. Możemy zauważyć, że nadzwyczaj silną pozycję na obszarze kijowszczyzny zdobyli Zamoyscy, którzy w owym czasie popierali m.in. Adama Kisiela będącego dopiero na progu wielkiej kariery politycznej. Czytelnik z łatwością zauważy również, jak ogromne wpływy wśród elit poselskich miał ród Wiśniowieckich. Warto pochwalić autora za to, że przedstawił biogramy osób mniej znanych w środowisku politycznym kraju.

Rozdział trzeci, będący zarazem podsumowaniem pracy, omawia konfiguracje rodzinne i polityczne kadry poselskiej na przestrzeni lat 1569-1648. Autor zagłębił się w tematykę siły politycznej danych rodów szlacheckich na obszarze kijowszczyzny. Autor zauważa, jak specyficzną rolę na tym obszarze odgrywał sejmik żytomierski, który stał się w owym czasie instrumentem gry politycznej Ostrogskich czy Wiśniowieckich.

Dzięki wsparciu potężnych rodów magnackich szczyt swojej potęgi, która przypada na lata dziewięćdziesiąte, osiągnęła rodzina Rużyńskich. W tym rozdziale 
została również poruszona sprawa rodziny Niemiryczów, którzy stanowią przykład frakcji politycznej znajdującej się na starcie wielkiej kariery politycznej.

W czasie lektury tego rozdziału czytelnik zauważa kolejne zmiany na kijowskiej scenie politycznej, które następują co kilka lat. Województwo kijowskie, tak jak inne kresowe obszary, staje się areną walki politycznej. O wpływy w tym województwie walkę podejmują m.in. rody Ostrogskich, Wiśniowieckich, Zamoyskich. Można zatem zauważyć, że układ polityczny był uzależniony od dwóch rodzajów wpływów, a mianowicie od oddziaływania kniaziowsko-magnackiego i od kręgów towarzysko-rodzinnych. Oczywiście ten drugi rodzaj oddziaływań często był uzależniony od wstawiennictwa najpotężniejszych rodów zamieszkałych na tym obszarze.

Omawiana praca jest rzetelnym przedstawieniem badanych przez Henryka Litwina zagadnień. Podkreślenia wymaga fakt, że praca została zaopatrzona w dużą liczbę tabel i zestawień statystycznych omawiających różnego rodzaju zagadnienia, jak np. struktury majątkowe czy wyznaniowe. Podjęta przez autora tematyka jednak nie do końca wyczerpuje badane zagadnienia. W kilku miejscach nasza wiedza mogłaby zostać uzupełniona, a przykładem jest tematyka związków politycznych klienteli z kresową magnaterią. Mimo tego możemy powiedzieć, że książka i prezentowane w niej konkluzje pozwalają ją uznać za jedno z ważniejszych opracowań dotyczących badanej tematyki.

Mikołaj Tomaszewski (Toruń)

\section{Ewangelicy w Toruniu $(X V I-X X$ w.), red. Jarosław Kłaczkow, Toruń 2011, ss. 502}

$\mathrm{W}$

ostatnich latach ujawnia się swoisty renesans zainteresowania historią lokalną. W badaniach nad mniejszościami religijnymi w Toruniu od lat ogniskuje swoje zainteresowania środowisko naukowe Torunia, pokłosiem czego było powstanie kilku ważnych prac zbiorowych wydanych, m.in. pod redakcją Mieczysława Wojciechowskiego (Mniejszości narodowe i wyznaniowe na Pomorzu w XIX i XX wieku, Toruń 1998), Ryszarda Sudzińskiego (Problemy narodowościowe i wyznaniowe na Pomorzu Nadwiślańskim i Kujawach w XX wieku, To- 